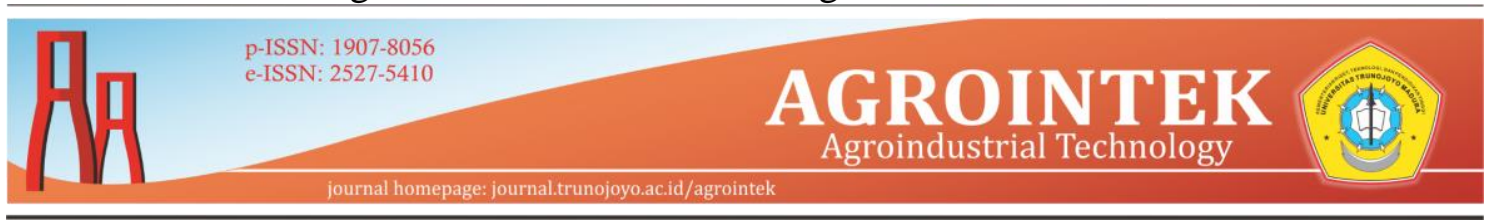

\title{
PHYSICAL CHANGES OF ANDALIMAN (ZANTHOXYLUM ACANTHOPODIUM DC.) IN PACKAGING DURING LOW- TEMPERATURE STORAGE
}

\author{
David S S Marpaung ${ }^{1 \dagger}$, Raizummi Fil'aini ${ }^{1}$, Amna Citra Fahrani ${ }^{1}$, Dwi Cahyani ${ }^{1}$, \\ Ayu Oshin Yap Sinaga ${ }^{2}$ \\ ${ }^{I}$ Department of Biosystems Engineering, Institut Teknologi Sumatera, Lampung Selatan, \\ Indonesia \\ ${ }^{2}$ Department of Biology, Institut Teknologi Sumatera, Lampung Selatan, Indonesia
}

Article history

Diterima: 14 Juli 2019

Diperbaiki: 30 Juli 2019

Disetujui: 31 Juli 2019

$\underline{\text { Keyword }}$

Andaliman,

Post-harvest,

Packaging,

Temperature Storage

\begin{abstract}
Zanthoxylum acanthopodium, locally known as andaliman, is one of exotic spices grown in North Sumatera. Several investigation shown that special taste and aroma comes from pericarp of andaliman. However, the pericarp of andaliman is easily degraded. The proper postharvest handling of andaliman is necessary to preserve fresh andaliman for long time. Previously, andaliman has been preserved in packaging under room temperature storage. Further investigation of andaliman preservation in packaging under low temperature storage would help reduce the postharvest losses. In this study, the physical changes of andaliman in various packaging under low-temperature storage were observed. The results shown that within 2 days, the pericarp of andaliman in paper packaging was shrunk, similarly found in control without packaging. Meanwhile, the pericarp of andaliman in aluminum foil and PP plastic were found normal in day 3. This result indicated that in low-temperature, andaliman in Aluminum foil was recommended for best postharvest handling.
\end{abstract}

(C) all right reserved

\footnotetext{
$\dagger$ Corresponding author

Email: david.marpaung@tb.itera.ac.id

DOI: http://dx.doi.org/10.21107/agrointek.v13i2.5543
} 


\section{INTRODUCTION}

Zanthoxylum acanthopodium, well known as andaliman, is an endemic plant grown in North Sumatera, Indonesia and commonly used as a spice for food and potentially as a herbal medicine. As a geographical product from Toba Samosir, North Sumatera, andaliman could help improve the economical profit for people in such area (Sembiring, 2017). Among of North Sumatera spices, andaliman is one of desirable spices, due to its unique taste and aroma from its pericarp. The special tastes of andaliman come from induction of trigeminal sensation. Sanshool ((2E,6Z,8E,10E)-N-(2'methylpropyl)-

dodecatetraenamide) play important role for induction of trigeminal sensation (Wijaya et al., 2018). Meanwhile, citronellal dan limonene hold the responsibility for induction of unique aroma of Andaliman (Wijaya et al., 2002). Beside its unique tastes and aroma, andaliman also potentially work as a herbal medicine, due to its medicinal function, such as anti-bacterial (Majumder et al., 2014), anti-radical (Suryanto et al., 2004), anti-inflamatory (Yanti et al., 2011), anti-cancer (Anggreini et al., 2014), anti-acne, anti-aging (Hanum et al., 2016), and anti-diabetic (Yanti and Limas, 2019). Andaliman as a spices for food is not only tasty, but also healthy to be consume.

The benefit of andaliman was led by its pericarp. Marpaung et al. (2019), found that most people prefer andaliman with pericarp compare to andaliman without pericarp, in terms of aroma and taste. However, the pericarp is easily damaged by environment and processing activities. Marpaung et al. (2019), found that in room temperature condition, within 2 days storage, the pericarp had been naturally removed from its kernel. There is not much literature disccused about postharvest handling of andaliman.
Therefore, the proper postharvest handling of andaliman is important to be developed, in order to preserve the quality. The effort to preserve the quality of andaliman has been done by several work, such as drying and packaging (Napitupulu, 2014; Marpaung et al., 2019). The best drying method for andaliman was oven drying. However, the pericarp is still easily broken caused by heat. In order to tackle the easily degraded of andaliman pericarp, the packaging could be promises method. The packaging with aluminum paper was shown able to keep the pericarp during room temperature storage within 3 days. Further investigation of andaliman physical changes in low temperature is necessary conducted for proper packaging design of andaliman. Low temperature storage, where agricultural products are stored at a temperature below the thermal tolerance of the pests, provides a good alternative for andaliman preservation. In addition, temperature also may affects metabolic activities, possibly affecting andaliman quality and shelf-life. This study investigated the physical changes of andaliman in various packaging during low temperature storage.

\section{METHODS}

\section{Materials}

The fresh andaliman was obtained from Kabupaten Toba Samosir, Sumatera Utara. One day after harvested by farmer, andaliman was sent to Institut Teknologi Sumatera, Lampung, used plastic as primary packaging and cardboard as secondary packaging. Andaliman was cleaned and separated manually using scissor.

\section{Tools}

Alumina paper, PP plastic, ruler, digital scale, thermometer, refrigerator, android mobile phone camera, and other additional tools. 


\section{Andaliman Packaging}

The sortation of fresh andaliman for packaging was conducted manually. The aluminum foil, paper and polipropilen plastic were used as packaging in this study. Andaliman stored in without packaging was used as control variable. Andaliman 0.3 gram was measured using scale, then put in packaging. The andaliman stored in refrigerator and temperature in refrigerator was measured by thermometer.

\section{Physical Changes Analysis}

Andaliman physical changes was observed by the colour changes and pericarp condition by visual observation. The picture was captured each day until 3 days storage. The physical change was observed to the condition of andaliman under low-temperature storage.

\section{RESULTS AND DISCUSSION}

The main purpose of agricultural product packaging is to reduce loses during postharvest handling. Beside packaging, low-temperature storage able to reduce postharvest loses. In this study, the physical changes of andaliman in various packaging under low-temperature storage were observed. The pericarp condition was observed as physical changes. Investigation of andaliman physical changes would be helped for further postharvest handling for famer, trader and consumer. The aluminum foil, PP plastic, and paper were used as andaliman packaging (Figure 1). The temperature of refrigerator was measured using thermometer, it was $8^{\circ} \mathrm{C}$.

The result of this experiment was showed in Figure 2 and Table 1. Within 2 days, the pericarp of andaliman in paper packaging was shrunk, similarly found in control without packaging. Meanwhile, the pericarp of andaliman in aluminum foil and PP plastic were found normal in day 3. Previous study (Marpaung et al., 2019), showed that andaliman was preserved in aluminum foil within 3 days in room temperature storage. In other treatment, andaliman pericarp was peeled and contaminated from unknown microorganism. Andaliman with no pericarp indicated the over ripped and losses the typical flavor of andaliman (Wijaya et al., 2018). In addition, Marpaung et al. (2019) also showed that the pericarp peeled of Andaliman affected trigeminal sensation and aroma sensory acceptance. Fresh andaliman with good condition of pericarp got higher score of aroma and taste compared to other maturity level as indicated by different colour and pericarp condition.

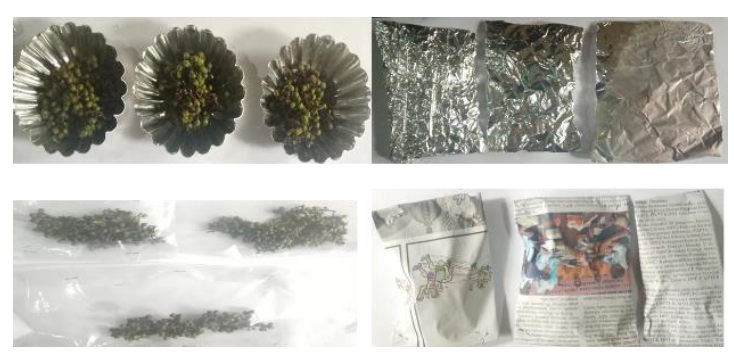

Figure 1 Packaging of andaliman before stored in low-temperature storage

Andaliman is an easily degraded agricultural product. In order to solve andaliman postharvest problem, proper postharvest handling is necessary developed. However, further investigation of andaliman postharvest handling is rare. One of investigation for andaliman postharvest handling is drying (Napitupulu, 2014).

Drying is an method to preserve agricultural product through decrease the water content. Among of drying methods tried, such as sun drying, wind drying, oven drying, far infrared drying-oven type, fluidized bed drying, and freeze drying, the optimum drying method to preserve andaliman quality based on the quality of the chemical, physical, sensory, and economic considerations was oven drying. Further investigation of 
combination of drying method and packaging method in low temperature may resulted long term shelf life.

In this study, the best packaging for andaliman stored in low-temperature was aluminum foil. Lamberti and Escher (2007), also found the best packaging method to preserve piper nigrum was used aluminum foil. Aluminum foil is suitable for sensitive agricultural product to light, oxygen and other products that easily loss the water content or other aromatic compound. The PP plastic could be served as andaliman packaging in lowtemperature storage, due to its low cost. In room temperature storage, aluminum foil preserved andaliman better compared to other packaging. Andaliman with PP plastic packaging was found contaminated from microorganism in day 3 in room temperature storage. Further investigation of long storage effect on andaliman packaging would be interesting, since the distribution of andaliman from North Sumatera to other provinces needs more than 3 days. Investigation of various temperature, packaging are also important to be explored for better andaliman preservation. The rare literature of research about postharvest handling of andaliman also brings more interests to develop more research about andaliman.

\section{CONCLUSION}

The aim of this study was to investigate the physical changes of andaliman in packaging under lowtemperature storage. Under $8{ }^{\circ} \mathrm{C}$ temperature storage, packaging using aluminum foil and plastic PP was able to preserve andaliman for 3 days.

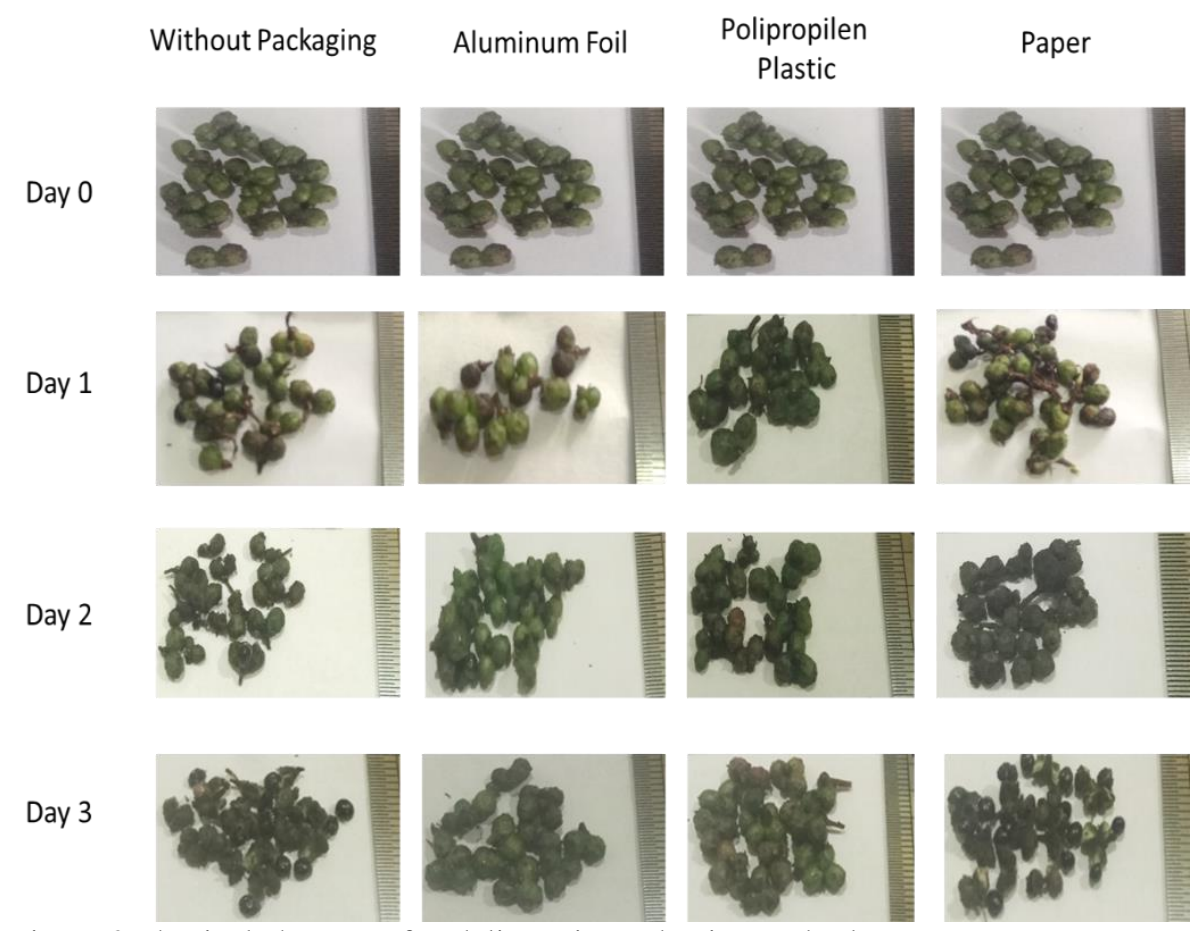

Figure 2 Physical changes of andaliman in packaging under low-temperature storage 
Table 1 Andaliman condition under low-temperature storage

\begin{tabular}{cccc}
\hline \multirow{2}{*}{ Treatment } & \multirow{2}{*}{ Day- } & \multicolumn{2}{c}{ Physical Changes } \\
\cline { 2 - 4 } & 0 & Pericarp & Colour \\
\hline \multirow{2}{*}{ Without } & 1 & Normal & Green \\
Packaging & 2 & The pericarp shrunk & Dark Green \\
& 3 & The pericarp peeled & Black \\
& 0 & Normal & Black \\
\hline \multirow{2}{*}{ Aluminum } & 1 & Normal & Green \\
Foil & 2 & Normal & Green \\
& 3 & Normal & Green \\
& 0 & Normal & Dark Green \\
PE Plastic & 1 & Normal & Green \\
& 2 & Normal & Green \\
& 3 & Normal & Dark Green \\
& 0 & Normal & Dark Green \\
\hline \multirow{2}{*}{ Paper } & 1 & Normal & Green \\
& 2 & The pericarp shrunk & Green \\
& 3 & The pericarp peeled & Dark Green \\
& & & Black \\
\hline
\end{tabular}

\section{REFERENCES}

Sembiring, M. 2017. Perlindungan Hukum terhadap Andaliman (Merica Batak) Sebagai Indikasi Geografis di Kabupaten Toba Samosir. Masalah-Masalah Hukum, 46(4), 318-327

Wijaya, C.H., Napitupulu, F.I., Karnady, V. and Indariani, S. 2018. A review of the bioactivity and flavor properties of the exotic spice "andaliman" (Zanthoxylum acanthopodium DC.). Food Reviews International, 1-19.

Wijaya, C.H., Hadiprodjo, I.T. and Apriyantono, A. 2002a. Identification of Volatile Compounds and Key Aroma Compounds of Andaliman Fruit (Zanthoxylum Acanthopodium DC.). Food Sci. Biotechnol 2, 680-683.
Suryanto, E., Sastrohamidjojo, H., Raharjo, S. and Tranggono. 2004. Antiradical Activity of Andaliman (Z. Acanthopodium DC.) Fruit Extract. Ind. Food and Nutri. 11, 15-19.

Yanti, T.E.P., Nuriasari, N. and Juliana, K. 2011. Lemon Pepper Fruit Extract (Zanthoxylum Acanthopodium DC.) Suppresses the Expression of Inflammatory Mediators in LipopolysaccharideInduced Macrophages in Vitro. American J. Biochem. And Biotechnol. 7. 190-195.

Majumder, M., Sharma, H.K., Zaman, K. and Lyngdoh, W. 2014. Evaluation of Physico-Chemical Properties and Antibacterial Activity of the Essential Oil Obtained from the Fruits of Zanthoxylum Acanthopodium DC. Collected from Meghalaya, India. Inter. J. Of Pharm. And Pharmaceu. Sci. 6, 543-546. 
Hanum, T.I. and Laila, L. 2016. Physical Evaluation of Anti-Aging and AntiAcne Andaliman (Zanthoxylum Acanthopodium DC.) Ethanolic Extract Peel off Gel Mask. Der Pharma Chemica. 8, 6-10.

Anggraeni, R., Hadisahputra, S., Silalahi, J. and Satria, D. 2014. Combinational Effects of Ethyl Acetate Extract of Zanthoxylum Acanthopodium DC. With Doxorubicin on T47D Breast Cancer Cells. Inter. J. Of PharmTech Res. 6, 2032-2035.

Yanti, Limas, R.W. 2019. Chemical profiling of Zanthoxylum acanthopodium essential oil and its antidiabetic activity. Food Research 3 (5) : $422-427$

Napitupulu, F.I.R. 2014. Metode Pengeringan Andaliman (Zanthoxylum acanthopodium DC.) untuk Memperoleh Mutu Sensori Aroma dan Sensasi Trigeminal. (Tesis) Departemen Ilmu dan Teknologi Pangan Fakultas Teknologi Pertanian. IPB. Bogor

Marpaung, D. S. S. Fil'aini, R. Fahrani, A. C. Cahyani, D. Putra, G. A. Sinaga, A. O. Y. 2019. Sensory Properties and Physical Changes in Packaging during storage of Exotic North Sumatera Spices Andaliman (Zanthoxylum Acanthopodium DC.) Prosiding Seminar Nasional Teknologi Pascapanen
Lamberti, M. and Escher. 2007. Aluminium Foil as a Food Packaging Material in Comparison with Other Materials. Food Reviews International, 23:4, 407-433 